обеспечивающих баланс сосуществования общества и природы, охрану природы и сбалансированное природопользование.

В настоящее время создалось сложное состояние взаимоотношений между людьми и природой, характеризующееся ресурсноэкологической достижимостью биосферы. Для этого требуется создание системы экологического мониторинга путем длительных наблюдений, оценивания и прогноза изменения состояния окружающей среды с целью защиты жизненно ценных интересов человека, общества, природы и государства от фактических и потенциальных угроз в связи с влиянием антропогенных или природных воздействий на окружающую среду.

Таким образом, как видим, понятие экологической безопасности не имеет однозначного понимания и требует дальнейшего научного осмысления.

Поскольку человечество вступило в эпоху научно-технического прогресса, где научнотеоретическая и техническая деятельность сблизились с целью создания техносферы создавшую новую среду обитания, изменившую ритмы нашей жизни поэтому экологическая безопасность окружающей среды важнейший этап развития. Успешное социально-экономическое развитие общества предполагает все более активные человеческие действия с различными компонентами природной среды. Природные объекты используются в качестве источников энергии, продуктов производства и потребительских товаров.

C возникновением техносферы масштабы ущерба от технологических катастроф стали сопоставимы с аналогичными показателями стихийных бедствий.

Решение проблематики экологической безопасности состоит в восстановлении баланса, что представляет собой задачу глобального масштаба.

\section{Литература:}

1.Мусабаева Н.А. Правовое регулирование обеспечения экологической безопасности Кыргызской Республики: Автореф. канд. юрид. наук. - Ош, 2014. - 26 с.

2.Безопасность Евразии: Энцикл. Словарь. М.: Книга, и бизнес, 2003. - 540 с.

3.Экологический энциклопедический словарь. - М.: Ноосфера, 1999. - 930 с.

4.Рекомендательный законодательный акт «О принципах экологической безопасности в государствах содружества».

5.Экологическая безопасность Кыргызстана. Б., 1998. -61 с.

6.Туратбеков А.Т. Генезис экологической безопасности // Вестник Академии МВД Кыргызской Республики. - 2014. - Вып. 4.C. $180-182$.

ОНТОЛОГО-ГНОСЕОЛОГИЧЕСКОЕ ЗНАЧЕНИЕ НАЦИОНАЛЬНЫХ ТРАДИЦИЙ

DOI: 10.31618/ESU.2413-9335.2021.1.86.1362

Асанов Жаныш Канатович

кандидат философских наук, старший научный сотрудник

(Кыргызстан, г.Бишкек);

Смутко Алексей Николаевич

кандидат философских наук, старший научный сотрудник

(Кыргызстан, г.Бишкек).

\title{
ONTOLOGICAL AND EPISTEMOLOGICAL SIGNIFICANCE OF NATIONAL TRADITIONS
}

\author{
Asanov Zhanysh Kanatovich \\ candidate of Philosophy, Senior Researcher \\ (Kyrgyzstan, Bishkek); \\ Smutko Aleksei Nikolaevich \\ candidate of Philosophy, Senior Researcher
}

(Kyrgyzstan, Bishkek).

\begin{abstract}
АННОТАЦИЯ
В данной статье рассматривается онтолого-гносеологическое значение национальных традиций, также в ней говорится о том, что понятие «национальная традиция» представляет собой как бы зафиксированную форму духовно--практической, познавательной деятельности субъекта по освоению имманентного содержания изменяющейся целостности-системы социумов глобализирующемся мире, в частности в Кыргызстане, главным образом в контексте соотносительности, взаимности, события человека, людей, нации, этносов и мирового сообщества.

ANNOTATION

This article examines the ontological and epistemological meaning of national traditions, it also says that the concept of "national tradition" is, as it were, a fixed form of spiritual - practical, cognitive activity of the subject for the development of the immanent content of the changing integrity-system of societies in the globalizing world, in particular in Kyrgyzstan, mainly in the context of relativity, reciprocity, events of a person, people, nation, ethnic groups and the world community.
\end{abstract}


Ключевые слова: национальные традиции, сущность, явление, содержание, форма, необходимость, случайность, пространство, время, универсальность.

Key words: national traditions, essence, phenomenon, content, form, necessity, chance, space, time, universality.

Национальная традиция по своей онтологогносеологической определенности есть логическая конструкция, принадлежащая к сфере социальной целостности. Она тесно связана с такими категориями, как «сущность» и «явление», «содержание» и «форма», «необходимость» и «случайность» и др., в которых выражается объективный эпистемологический процесс более глубокого проникновения в сущность постигаемых вещей и явлений. При этом понятие «национальная традиция» (в единстве с другими сопредельными категориями) приближаясь к охвату цельной картины общественного бытия, представляя собой логическое средство, в форме которого адекватно отражают особенности функционирования и развития культурноцивилизационной системы.

Осваивая человеком, т.е. субъектом современного социального познания, национальная традиция, ставшая предметного для философской, культурологической и социально-психологической и др. науки, выступая как выражение, воспроизведение и логическое постижение, соотносительности, события нации и общественной целостности, представляет собой единство абсолютного и относительного, бесконечного м конечного, изменчивости и устойчивости, одновременности и последовательности и др. С этой позиции национальная традиция включает в себя противоположные (но взаимообусловленные) явления в контексте развития нации и этносов к миру социального.

Абсолютность национальной традиции означает универсальность, имманентность и обязательность ее проявления на всех этапах развития человеческой цивилизации, взаимодействия людей, этносов, нации и социумов. Тем самым абсолютность национальной традиции обнаруживается через ее конкретные формообразования, для которых характерны разнообразие качественных определенностей, специфические дифференциации и интеграции, субординации и иерархии, переходы и переливы, усложнения, неоднородная смыслосодержательность и др. В этом и выражается относительность национальной традиции [1].

В этом ряду онтологическое содержание категории «бесконечное» и «конечное» своеобразно выражает неразрывно связанные, но противоположные стороны национальной традиции. Так, бесконечность означает: а) функционирование национальной традиции в цивилизационном пространстве и социальном времени, неограниченное многообразие ее проявления, их принципиальную «незамкнутость», т.е. разновидности данного социально-культурного феномена являет собой важнейшим элементом индивидуального и общественного сознания; показателем самореализации, самоутверждения человека как личности, нации как этносоциальной общности, «субъективизации» явлений социальной действительности; б) количественную неисчерпаемость бытия национальной традиции; в) качественную неоднородность форм и типов функционирования национальной традиции в системе духовной жизни общества.

Из диалектического единства абсолютного и относительного, бесконечного и конечного в национальной традиции мы часто приходим к двум противоположным утверждениям: вопервых, все формы проявления национальной традиции так или иначе взаимосвязаны и взаимодетерминированы, что вытекает из принципа всеобщей связи явлений мира; вовторых, в рамках той или иной разновидности национальной традиции отсутствуют непосредственная связь и обусловленность со всеми объектами социального мира.

Национальная традиция имеет свою историю, логику развития, т.е. возникает, развивается и функционирует, в ходе самореализации данного феномена, повышается ее ценность, содержательность, что во многом зависит от гуманистической целесообразной деятельности людей, нации и социумов. Тем самым национальная традиция выражает сложность, противоречивость субъектобъектных взаимообусловленностей, соотносительность, последовательность социально-культурных явлений, их протяженность, субстанционально-генетические связи, смыслосодержательные моменты, многообразие отношения людей, нации и этносов к общественной действительности. Иными словами, она, обозначая сущность пространственно-временного бытия человека, нации, народов и социумов в их соотносительности, взаимоотношении, представляет собой диалектическое единство одновременности и последовательности, которые неразрывно связаны между собой и постоянно переходят друг в друга. Одновременность национальной традиции означает, что ее разновидности, смыслосодержательные признаки сосуществуют, как бы сохраняются, в то же время как последовательность - ее непрерывное изменение и обновление [3].

Следует отметить, что понятие «национальная традиция» представляет собой как бы зафиксированную форму духовно-практической, познавательной деятельности субъекта по освоению имманентного содержания 
изменяющейся целостности-системы социумов глобализирующемся мире, в частности в Кыргызстане, главным образом, в контексте соотносительности, взаимности, события человека, людей, нации, этносов и мирового сообщества. Тем самым данное понятие, являясь своеобразным «пунктом», «узлом» и уровнем непрерывно развивающегося познания объектов социальной системы, выступает как диалектический процесс, развертывающий в геосоциальном, поликультурном пространстве, ибо эта категориальная определенность постоянно развивается, обогащается, углубляется, конкретизируется в ходе духовнопрактического, рефлексивно-теоретического постижения форм бытия, в частности, системы национальных традиций как единство многообразного. Диалектика данного понятия означает переход от изучения сущности первого порядка национальной традиции к познанию, логическому воспроизведению ее сущности второго, третьего...бесконечного (неисчерпаемого) порядка.

Таким образом, феномен национальной традиции следует рассматривать как с онтологических, так и с логикогносеологических позиций. В онтологическом аспекте национальная традиция как многообразное социокультурное явление, как форма бытия выступает неотъемлемой существенной характеристикой отношения людей, этническо-национальной определенности к общественной целостности. Национальная традиция и формы развертывания ее бытия -неисчерпаемые предметные области научнотеоретического, в том числе и социального, историко-философского познания [2].

В логико-гносеологическом аспекте национальная традиция представляется как исходная категория (форма мышления, типа связи предиката в суждении) социальной философии, широко используемая в научном познании реальной действительности. В целом «национальная традиция»- это не простое отражение, а теоретическое воспроизведение и духовно-практическое освоение, логическое постижение соотносительности, взаимности, обоюдной причастности людей, нации, этноса и социума в контексте активной предметной деятельности субъекта. И как следствие, данное понятие имеет деятельностное происхождение, ибо, будучи своеобразной формой рациональности, рубрикации, мысли, оно возникает, становится и формируется, постоянно обогащается, развивается в ходе социальной практики и является моментом последовательного проникновения духовнонравственного, интеллектуального мира людей в мир социального бытия. Тем самым, став предметом научно-теоретического поиска, национальная традиция, системно выражая ценностно-культурного, духовно-нравственного и гуманного отношения субъектов (нации или этноса) к социальной целостности, носит диалектический характер, т.е. закономерно разнообразится, функционирует, организует свое бытие в социальном, социоприродном пространственно-временном континууме, показывает ценности, самоценности человека, (нации, этноса) людей и социумов, их совместной жизнедеятельности.

Национальные традиции содержат в себе такие гуманистические, аксиологические ориентиры как толерантность, высокая мобильность, свобода выбора, права человека, законопослушность, гражданское самоопределение, диалог культур, религиозных конфессий, позволяющий формировать у людей представление о единстве мира в его разнообразии, устойчивом развитии, связях мировоззренческих ориентиров личности с ценностями, доминирующими в этническонациональной культуре. Индивидуальный подход к сущности национальной традиции как составляющая личностного духа включает психологическую диагностику, учет возрастных и индивидуальных особенностей конкретного человека, но и национального интереса, национального самосознания людей, прогнозирования их развития.

Таким образом, из вышеизложенного следует, что система национальных традиций выражая особенности проявления общечеловеческих традиций в контексте взаимодействия субъекта и объекта этническо-национальных отношений, организует свое конкретно-целостное бытие в диалектике социумов. Национальные традиции в целом представляют собой развивающееся социокультурное явление, которое выступает как атрибутивное свойство этноическо-национальной общности, обеспечивающее ее целостность и самотождественность (самоидентичность) в процессе воспроизводства комплекса существенных черт духовного облика нации.

\section{Литература}

1. ЖУМАГУЛОВ М.Ж. ОНТОЛОГИЯ ЭКОЛОГИЧЕСКОЙ ЭТИКИ. Б., 2010. -С. 127.
2. МЕДЕДОВ Ж.К.
ПОНЯТИЕ

ТРАДИЦИИ В СИСТЕМЕ РАСШИРЕННОГО ПОРЯДКА: АВТОРЕФЕРАТ ДИССЕРТАЦИИ КАНД.ФИЛОС.НАУК. -АЛМА-АТА, 1995. -С. 13.

3. ЧЕРЕПАНОВА Н.В. ТРАДИЦИИ КАК СОЦИОКУЛЬТУРНЫЙ ФЕНОМЕН. // ТРУДЫ СГУ. ВЫП.94. ГУМАНИТАРНЫЕ НАУКИ. РАБОТЫ АСПИРАНТОВ И СОИСКАТЕЛЕЙ. М.: 2006. -C. 63. 